\title{
Strategic Human Resource Management, Regulatory Violation and Job Satisfaction in Malaysia
}

Ema Sulisnaningrum

(STIE Jaya Negara Tamansiswa Malang)

Agatha Braun

(Humboldt University of Berlin)

\begin{abstract}
This study aims to determine the level of employee job satisfaction, employee compliance with work regulations and human resource management strategies by conducting online interviews with 512 government and private employees in Malaysia by random sampling, then quantifying for regression using the autoregression moving average model. We find that the level of employee satisfaction is positively related to employee compliance with job regulations and the level of quality of strategic resource management in companies or government agencies.
\end{abstract}

Keywords: Human Resource Management, Job Satisfaction, Employees

\section{Background}

Strategic Management is the process of analyzing and creating strategies as well as implementing and monitoring on an ongoing basis by an organization with the aim of achieving and maintaining its competitive advantage. Strategic Management can also be defined as the art and science used to formulate, implement and evaluate cross-functional decisions that enable an organization to achieve its goals (Amason,2011). With this Strategic Management, an organization or company can assess the business and industry it is engaged in, including assessing its competitors and setting goals for its organization to outperform its current and future competitors and then reassessing each of its organizational strategies. Human Resource (HR) Strategic Management is the practice of aligning business strategy with HR practices to achieve organizational strategic goals. The aim of Strategic HR Management is to ensure that the HR strategy is not a means, but an end in itself as far as business goals are concerned. Companies must adapt their HR strategy within the framework of the overall Business objectives and hence ensure that there is alignment between HR practices and the strategic objectives of the organization (Gupta,2020).

Company performance requires an asset which is called a resource, both natural resources, capital resources and human resources. Both of these resources are very important in determining the success of a business. But if the question is, which one is more important among all types of resources, then it is human resources that are important. The urgency of this very prominent human element is reasonable because today's management thinking patterns are based or oriented towards the human factor as the most important element of management itself. This pattern also translates to the success or 
failure of a management process to a large extent determined by the human factors involved in the management process concerned. Because in principle and implementation of the management concerned, the human factor needs to be the main consideration because human resources determine the effectiveness of business success. Employees in a company are the most important resource to support the achievement of the vision and mission that has been made. Therefore, employee job satisfaction will be the centre of attention for HR in the company. The more an employee feels comfortable and satisfied with his job, the more he works and thinks creatively for the progress of the company. Employee job satisfaction has now become the centre of attention for HR in the company. Given that employees are the most important asset in the company, it is important for companies to maintain employee motivation and job satisfaction. Employees who feel happy at work will have a positive impact, while on the other hand, employees who are not satisfied can actually backfire for the company. Job satisfaction is a term used to describe employee happiness and satisfaction in meeting their needs in the workplace. Satisfaction is not only obtained from salaries and benefits alone. There are many factors that contribute to employee job satisfaction, such as appreciation, compensation, flexibility, management and work culture. HR should make employee job satisfaction one of the goals that need to be achieved. High satisfaction, because it will not only have an impact on employee performance but as a means of company branding, both internally and externally (Mathew et al,2020).

\section{Literature Review}

In a company, human resources or employees will be managed by a division called Human Resource (HR). The aim is to develop the company through the application of all corporate values and culture. Strategic human resource management policies greatly affect attitudes and behaviours that have an impact on employees as a whole. Because they are related to company values and culture, human resources must be properly selected before being accepted to join the company. The selection process of managing employees is included in human resource management. HR management has a very large contribution to the company's efforts in achieving its goals. This of course cannot be separated from the role of the HR management function which makes employee management easier (Fazey,2020). Employee management must be carried out through an organizational process that can strengthen individual competencies and organizational capabilities. Employee management must be designed to create value and results that contribute to the organization's strategy. Many business organizations today exhibit changes and environmental dynamics that require organizations to adapt. So that often every organization is required to have the ability to adapt to the environment, including changes in employee policies and management in order to retain employees through change management. The result of change management for employees is the capacity to change. Employees as business partners help to let go of the old culture and adapt to the new one. This role is known as an agent of change (Armstrong \& Taylor,2020).

Strategic human resource management is a process of managing organizational human resources from an organizational strategic perspective that links HR management to organizational strategy so that Human Resource Management can support the achievement of organizational strategy. Human resource management strategy requires great attention and support from all capacities of the organization because it is related to organizational learning efforts both learning about the organizational environment, organizational performance, organizational goals, organizational capabilities, and learning to make a change. Strategic management is the process of setting organizational goals, developing policies and planning to achieve these goals, and allocating resources to implement policies and plan for achieving organizational goals. Strategic management combines the 
activities of various functional parts of a business to achieve organizational goals. Strategic management talks about the big picture. The essence of strategic management is identifying the goals of the organization, its resources, and how these resources can be used most effectively to meet strategic objectives. Strategic management at this time must provide the basic foundation or guidelines for decision making in the organization. It is a continuous and persistent process. The strategic plan of the organization is a living document that is always visited and revisited. It may even need to be considered fluid because of its constantly modified nature. As new information becomes available, it should be used to make adjustments and revisions (Storey et al,2019). Good and ideal leadership grows not only based on the long work experience a leader has but also how a leader can take advantage of every potential in him, have behaviours and attitudes as well as a competent work style to face the digital era. Order is needed in maintaining company performance. Every company has the right to impose sanctions on its employees who deliberately make mistakes or negligence. Therefore, employees must obey the existing rules of the company where they work. If employees violate these rules, it is possible that employees who violate them will be given the applicable sanctions. job satisfaction minimizes violations in the company and improves performance. Job Satisfaction is an emotional attitude that is fun and loves his job. This attitude is reflected by work morale, discipline and work performance. Job satisfaction is enjoyed at work, outside work, and a combination of inside and outside work (Agodu,2019).

\section{Research Methods}

Collecting data in this study using interviews with 512 government and private employees in Malaysia by random sampling. Then, quantify the regression using the autoregression moving average model. The interview aims to extract data in the form of employee satisfaction levels, employee compliance, quality levels of strategic resource management. We use average data or all the data obtained is averaged based on a group of variables determined based on literature review and background and time series, after that, we perform regression using the moving average model autoregression method with the following equation:

$S_{t}=C_{t}+\beta_{1} E_{t 1}+\beta_{2} H_{R M S}+e_{t}$

Where,

$\mathrm{S}=$ level of employee satisfaction

$\mathrm{E}=$ Employee compliance

HRMS = Quality level of strategic resource management $\mathrm{e}=$ Term Error

\section{Results and Discussion}

The estimation results are as follows:

$\mathrm{S}=-0.513715224282+0.0482711369825 * \mathrm{E}+0.867491442812 * \mathrm{HRMS}$

From the estimation results, the level of employee compliance and the level of quality of strategic human resource management has a positive effect on the level of employee satisfaction. Where every $1 \%$ increase in the level of employee satisfaction is followed by an increase in employee compliance 
by $0.05 \%$ and the quality of strategic human resource management by $0.9 \%$ which is briefly described in Table 1 illustrates the estimation results as follows:

Table 1. Estimation Results

\begin{tabular}{|c|c|c|c|c|}
\hline Variable & Coefficient & Std. Error & t-Statistic & Prob. \\
\hline $\mathrm{C}$ & -0.513715 & 1.249629 & -0.482388 & 0.6357 \\
\hline $\mathrm{E}$ & 0.048271 & 0.228196 & 0.242306 & 0.8114 \\
\hline HRMS & 0.867491 & 0.210936 & 4.535938 & 0.0003 \\
\hline R-squared & 0.835511 & \multicolumn{2}{|c|}{ Mean dependent var } & 7.25 \\
\hline Adjusted R-squared & 0.813218 & \multicolumn{2}{|c|}{ S.D. dependent var } & 1.446411 \\
\hline S.E. of regression & $8.01 \mathrm{E}-01$ & \multicolumn{2}{|c|}{ Akaike info criterion } & 2.531911 \\
\hline Sum squared resid & 10.91095 & \multicolumn{2}{|c|}{ Schwarz criterion } & 2.681271 \\
\hline Log likelihood & -22.31911 & \multicolumn{2}{|c|}{ Hannan-Quinn criter. } & 2.561068 \\
\hline F-statistic & 22.4666 & \multicolumn{2}{|c|}{ Durbin-Watson stat } & 1.653996 \\
\hline Prob(F-statistic) & \multicolumn{4}{|c|}{0.000017} \\
\hline
\end{tabular}

Based on the estimation results described in Table 1. The level of employee satisfaction reflects the level of employee compliance and the level of quality of strategic human resource management. This proves that human resource management is important to maintain the level of employee job satisfaction which in turn has an impact on employee performance.

\section{Conclusion}

Employee job satisfaction is very important to maintain employee loyalty and employee performance so that they can make the best contribution to the company. Employee satisfaction is positively related to the quality level of strategic human resource management and the level of employee compliance in the company. When employees are satisfied, performance improvements can occur. Job satisfaction, compliance levels and human resource strategy are interrelated in Malaysia.

\section{Reference :}

Agodu,I.(2019).Leadership Styles and Companies' Success in Innovation and Job Satisfaction A Correlational Study.Bloomington : iUniverse

Amason,A.(2011).Strategic Management: From Theory to Practice.London : Routledge

Armstrong,M., Taylor,S.(2020).Armstrong's Handbook of Human Resource Management Practice. London: Kogan Page Publishers.

Fazey,M.(2020).Human Resource Policy: Connecting Strategy with Real-World Practice. London : Anthem Press

Gupta,A.D.(2020).Strategic Human Resource Management. London : CRC Press

Mathew,P., Song,J. ,Ferch,S.R.(2020).Global Servant-Leadership: Wisdom, Love, and Legitimate Power in the Age of Chaos. Lanham : Rowman \& Littlefield

Storey,J., Ulrich,D. ,Wright,P.M.(2019).Strategic Human Resource Management: A Research Overview. London : Routledge 